\title{
STUDY OF CIGARETTE BUTTS EXTRACT AS CORROSIVEINHIBITING AGENT IN J55 STEEL MATERIAL
}

\author{
S.Vahidhabanu1, B.Rameshbabu' ${ }^{2}$, P. Suresh Babu ${ }^{3}$, H. Abdul Rahman ${ }^{4}$ \\ ${ }^{1,3}$ Department of Civil Engineering, Anna university, (BIT campus), Tiruchirappalli-620024, India \\ ${ }^{2}$ Pollution Control Division, CECRI (ACSIR Institute), Karaikudi - 630 006, Tamil Nadu, India \\ ${ }^{4}$ Department of Electronics and communication Engineering, SRM university, Kancheepuram-6032034, India
}

\begin{abstract}
Cigarette butts are the one of the most common garbage worldwide, as an estimated 4.5 trillion cigarette butts are deposited somewhere into the environment every year. Chemicals such as arsenic, nicotine, polycyclic aromatic hydrocarbons, and heavy metals have been found to leach into water and can be the source of toxicity to life in marine and freshwater environments. The present study is to isolate crude extracts from littered cigarette butts using polar solvents, which is used as corrosion inhibitor for J55 oil well tubular steel used in acidization of oil well and gas production. The chemical compounds present in the crude extracts analyzed using LC-MS and ASS. Weight loss and electrochemical techniques were used to evaluate corrosion inhibitive effects on J55 oil well tubular steel in $15 \% \mathrm{HCl}$ solution at $30^{\circ} \mathrm{C}$ and $105^{\circ} \mathrm{C}$.Result shows that the highest inhibition efficiencies of $99 \%$ and $61 \%$ are obtained for $30^{\circ} \mathrm{C}$ and $105^{\circ} \mathrm{C}$ respectively at $6 \%$ concentration.Hence delivered a potential remedial solution for the littered cigarette butts and provide a clean environment.
\end{abstract}

Keywords: cigarette butts, corrosion, inhibitor, environment, acidization

\section{INTRODUCTION}

It is an eminent fact that thousands of chemicals are found in cigarette smoke with dozens of these chemicals being identified as human and animal carcinogens (United States Department of Health and Human Services [USDHHS], 2010). However, it is not known if cigarette butts, which have become a huge litter problem in recent decades, can be a toxic risk and become a health risk to marine as well as freshwater habitats. One of effective ways to reduce pollution is introduced byrecycling the cigarette butts. But, there are few reports onreusing cigarette butts.

Acidization of petroleum oil well is a stimulation technique for enhancing production.Hydrochloric acid (15-20\%) solution is commonly used for the purpose. The $15 \% \mathrm{HCl}$ used for acidizing process leads to severe corrosion of oil well casing,tubing and accessories.The total annual cost of corrosion in the oil \&gas productions are estimated to be $\$ 1.372$ billion, broken down into $\$ 589$ million in surface pipeline and facility costs, $\$ 463$ million annually in down hole tubing expenses, and another $\$ 320$ million in capital expenditures related to corrosion (Matthew, May 2008.) corrosion inhibitors are added along with the acid to reduce the corrosion attack on well equipment.This study focuses on detecting specific chemicals present in the cigarette butts extract and used as a corrosion inhibitor for J55 steel pipe used in acidization process. In this investigation, $15 \%$ of hydrochloric acid and cigarette butt waterextracts on corrosion inhibition are taken into account.

\section{EXPERIMENTAL SECTION}

The tested material is J55 oil well tubular steel with the chemical composition of $\mathrm{C} 0.33, \mathrm{Mn} 1.45$, Si 0.25 , S 0.06 , P0.04and Fe 97.87.Before the corrosion test, the surfaces of the sample are mechanically polished and rinsed with Clark solution and then dried.The apparatuses used in this study are as follows: The chemical compositions of the cigarette buttwater extracts are detected by liquid chromatography (Agilent 2100)/mass spectrometry (Agilent 6410) with the followingdetermination conditions: C18 column $(2.1 \mathrm{~mm} \times 50$ $\mathrm{mm}, 3.5 \mu \mathrm{m}$, Agilent), column temperature $-30{ }^{\circ} \mathrm{C}$, mobile phasemethanol $+0.1 \%$ formic acid, flow rate $0.4 \mathrm{~mL} / \mathrm{min}$, sampling amount $2 \mu \mathrm{L}$, ion source model ESI+, atomizing gas pressure $15 \mathrm{psi}$, atomizing gas flow rate $6 \mathrm{~L} / \mathrm{h}$, atomizing gas temperature $350{ }^{\circ} \mathrm{C}$, capillary voltage $150 \mathrm{~V}$, scanning model full scanningmodel, direct sampling after filter by $0.45 \mu \mathrm{m}$ micro porous membrane. The electrochemical techniques such as potentiodynamic polarization and impedance are investigated by a potentiostat. The littered cigarette butts were used in this study.

\section{RESULTS AND DISCUSSION}

\subsection{Collection of Sample}

Sample (littered cigarettes) was collected from various places in Tiruchirappalli which includes airport, central bus stand, streets, sidewalks, and other open areas. All glassware's (Borosil) was washed and rinsedwith deionized water,and further sterilized at $120^{\circ} \mathrm{C}$ for 20 minutes prior to use. The 
collected cigarette butts were used for the preparation of crude extracts by using water as a polar solvent.

\subsection{Preparation of Inhibitor}

The methodology for making corrosion inhibitor with cigarette butt -water extracts is as follows: Five grams of littered cigarette butts were soaked in $100 \mathrm{~mL}$ of deionizedwater for seven days. Each container was sealed with paraffin strip and placed in a shaker conical flask covered with aluminum foil. The polar solvent sample was prepared. After 7 days the sample was filtered using vacuum pumpfor the removal of solid and suspended particlesand a filter paper made of cellulose fiber.The filter paper was $9.0 \mathrm{~cm}$ in diameter, with particle retention of 1-5 micrometer, fine porosity and a slow flow rate of 5 milliliter per minute. There was approximately 75-100 $\mathrm{mL}$ of liquid present in the conical flask after the 7 day period soaking. The volume of each sample depended on the sample itself. The amount of sample that was filtered was extracted using rotary evaporator (Make: IKA) and stored in a glass vials at room temperature. The cigarette butts extract was analyzed for corrosion inhibition by weight loss and electrochemical methods. The extract had also been determined by the LC/MS. In the rough, seven chemical compounds with the heteroatom $(\mathrm{N}, \mathrm{O})$ and $\pi$-bonds in favor of metal corrosion inhibition were detected in the LC/MS results. There may also be others it hasbeen not detected.Among them nicotine contain $1.43 \%$ high concentration.

\subsection{Presence of Heavy Metals in the Aqueous Extract}

The presence of heavy metals in the aqueous solution of cigarette butts extract as analyzed through atomic absorption spectroscopy the results are followed as

\begin{tabular}{|l|l|}
\hline Heavy metals & Concentration(mg/L) \\
\hline $\mathrm{Cu}$ & 0.72 \\
\hline $\mathrm{Fe}$ & 1.06 \\
\hline $\mathrm{Zn}$ & 0.02 \\
\hline $\mathrm{Cr}$ & 0.12 \\
\hline $\mathrm{Ni}$ & 0.21 \\
\hline
\end{tabular}

\subsection{Mass Loss Measurements}

The mass loss parameters of J55 oil well tubular steel in 15\% commercial $\mathrm{HCl}$ containing various concentrations of Cigarette Butt Water Extractsat $30^{\circ} \mathrm{C}$ and $105^{\circ} \mathrm{C}$ are given in Table 3. From the Table 3 , it can be observed that the corrosion rate values decrease and the inhibitor efficiency values increase with the increase of the Cigarette Butt Water Extracts concentrations for both the temperatures. But at a particular concentration of the inhibitors, the corrosion rate increases and the inhibitor efficiency decreases with the increase of temperature as can be observed from Table 3. It can also be observed that the corrosion rate values decrease from 165 mmpy to $1 \mathrm{mmpy}$ and from $427 \mathrm{mmpy}$ to $136 \mathrm{mmpy}$ for Cigarette Butt Water Extractsat $30^{\circ} \mathrm{C}$ and $105^{\circ} \mathrm{C}$ respectively.The highest inhibition efficiencies of $99 \%$ and $61 \%$ are observed for Cigarette Butt Water Extracts at $6 \%$ concentration and at $30^{\circ} \mathrm{C}$ and $105^{\circ} \mathrm{C}$, respectively. The addition of Cigarette Butt Water Extracts changes the corrosion rate and the inhibition efficiency.At higher temperature, Cigarette Butt Water Extracts is not an effective inhibitor.Figure. 1 shows the plot of inhibitor efficiency as a function of inhibitor concentration for both the temperatures.

\subsection{Potentiodynamic Polarization Measurements}

The polarization behaviors of J55 oil well tubular steel in $15 \%$ $\mathrm{HCl}$ and without various concentration of Cigarette Butt Water Extractsat $30^{\circ} \mathrm{C}$ and $105^{\circ} \mathrm{C}$ is shown in Fig.2. From these polarization curves, the polarization parameters like $E_{\text {corr }}$, ba, bc and $I_{\text {corr }}$ are obtained. From the values $I_{\text {corr }}$, the corrosion rates and inhibitor efficiencies are calculated and tabulated in Table 4. In the Cigarette Butt Water Extracts, it can be observed that the $\mathrm{I}_{\text {corr }}$ values decrease from $771 \mu \mathrm{A} . \mathrm{cm}^{-}$ 2 to $130 \mu \mathrm{A} . \mathrm{cm}^{-2}$ at $30^{\circ} \mathrm{C}$ and from $1,35,000 \mu \mathrm{A} . \mathrm{cm}^{-2}$ to $47,600 \mu \mathrm{A} \cdot \mathrm{cm}^{-2}$ at $105^{\circ} \mathrm{C}$. The highest inhibitor efficiency of $83 \%$ and $65 \%$ are achieved for both the temperatures respectively. From the $\mathrm{E}_{\text {corr }}$ values, it can be observed that there are tides in the $E_{\text {corr }}$ values for the inhibitors. This indicates clearly that Cigarette Butt Water Extractsare mixed type of inhibitors.

\subsection{Electrochemical Impedance Measurements}

The impedance behavior of J55 oil well tubular steel in $15 \%$ commercial $\mathrm{HCl}$ with and without various concentrations of inhibitor at $30^{\circ} \mathrm{C}$ and $105^{\circ} \mathrm{C}$ is shown in Figure.3. From these impedance curves, the impedance parameters like charge transfer resistance $\left(\mathrm{R}_{\mathrm{ct}}\right)$ and double layer capacitance $\left(\mathrm{C}_{\mathrm{dl}}\right)$ values are obtained. From the values of $\mathrm{R}_{\mathrm{ct}}$, the inhibitor efficiency is calculated and tabulated in Table 5. From this table, it can be observed that the $R_{c t}$ values of inhibitor increased from $32 \Omega \mathrm{cm}^{2}$ to $272 \Omega \mathrm{cm}^{2}$ respectively and $C_{\mathrm{dl}}$ values decreased from $265 \mu \mathrm{F} . \mathrm{cm}^{-2}$ to $32 \mu \mathrm{F} . \mathrm{cm}^{-2}$ respectively with the increase of the inhibitor concentrations. The decrease in $\mathrm{C}_{\mathrm{dl}}$ values indicates that the adsorption of inhibitor molecules on the J55 oil well tubular steel surface and the corrosion process involved is activation-controlled reaction. The plots $\Phi$ vs. $\log \mathrm{C}$ are drawn for Cigarette Butt Water Extractsinhibitors at $30^{\circ} \mathrm{C}$ and $105^{\circ} \mathrm{C}$ and they are shown in Figure.4. From these plots, it can be seen that the $\Phi$ vs. $\log \mathrm{C}$ curve is linear. This linear trend confirms that Cigarette Butt Water Extractsinhibitors obey Tem kin's adsorption isotherm at both the temperatures.From the above weight loss and electrochemical studies,cigarette butt water extracts may establish its inhibition actionvia the adsorption onto the metal surface. The adsorption of the inhibitor could be occurred due to the formation of oxidation film or the electrostatic 
interactions. The oxidants in inhibitor may oxidize the iron atoms forming the insoluble salt (oxidation film) covered on the iron surface. The lonely electron pairs present on the $\mathrm{N}$ and $\mathrm{O}$ atoms of the heterocyclic compounds in the inhibitor may also adsorb through the electrostatic interactions between the acid solution and the metal surface.Thus, the metal surface can be protected and the iron atom'sfurther dissolution can be prevented(Behpour, M etal.,Corros.Sci.2009).

\subsection{Effect of Temperature on Thermodynamic Properties}

The values of activation energy $\left(\mathrm{E}_{\mathrm{a}}\right)$, heat of adsorption $\left(\mathrm{Q}_{\mathrm{ads}}\right)$, free energy of adsorption $\left(\Delta \mathrm{G}^{\mathrm{o}} \mathrm{a}\right)$, Enthalpy $\left(\Delta \mathrm{H}^{\mathrm{o}} \mathrm{a}\right)$ and the Entropy $\left(\Delta \mathrm{S}^{\mathrm{o}} \mathrm{a}\right)$ are calculated for the studied system and given in Table 6. From the table, it can be found that the $E_{a}$ value of uninhibited system is $11380 \mathrm{~kJ} \mathrm{~mol}^{-1}$ and the values of inhibited systems of inhibitor are $60679 \mathrm{~kJ} \mathrm{~mol}^{-1}$. The $\mathrm{E}_{\mathrm{a}}$ value of the inhibited system is higher than the value of uninhibited system. The higher values indicate the physical adsorption of the inhibitor on the J55 steel surface ( I.N.Putilova et al.1960).The $\mathrm{Q}_{\mathrm{ads}}$ values of inhibitor is $-46337 \mathrm{~kJ} \mathrm{~mol}^{-1}$. As they are more negative, the temperature effect is there. As the temperature increases, the $\Delta \mathrm{G}^{\circ}$ a values for $30^{\circ} \mathrm{C}$ and $105^{\circ} \mathrm{C}$ decreases to more negative of -37333 and $-34953 \mathrm{~kJ} \mathrm{~mol}^{-1}$. It shows that the inhibitors are more efficient which suggests that the inhibitor is strongly adsorbed on the metal surface (J.D.Talati et al.1988). The $\Delta \mathrm{H}^{\mathrm{o}}$ a values are positive of 58160 and $57495 \mathrm{~kJ} \mathrm{~mol}^{-1}$ at $30^{\circ} \mathrm{C}$ and $105^{\circ} \mathrm{C}$ respectively, which indicate the endothermic nature of the reaction suggesting that higher temperature favors the corrosion process (D.Agarwal, et al. 2003). The $\Delta \mathrm{S}^{\mathrm{o}}$ a values are also positive of 58283 and $57586 \mathrm{~kJ} \mathrm{~mol}^{-1}$ at $30^{\circ} \mathrm{C}$ and $105^{\circ} \mathrm{C}$ respectively, which confirm that the corrosion process is entropically favorable (R.M.Issaet al.2002).

\subsection{Scanning Electron Microscopic Studies}

Figure.5 shows the surface morphology of the specimens immersed in $15 \% \mathrm{HCl}$ with and without $6 \%$ of inhibitor for 6 hours at $30^{\circ} \mathrm{C}$ and $105^{\circ} \mathrm{C}$. The microphotograph of Fig.5a represents the polished $\mathrm{J55}$ oil and gas well tubular steel, which has smooth and homogenous. Figure.5b and $5 \mathrm{c}$ represent the specimens immersed in $\mathrm{HCl}$ at $30^{\circ} \mathrm{C}$ and $105^{\circ} \mathrm{C}$. The entire surface is corroded with uniform attack, which corresponds to the maximum corrosion rate. Figure.5d and $5 \mathrm{e}$ represents the sample immersed in $6 \%$ inhibitor at $30^{\circ} \mathrm{C}$ and $105^{\circ} \mathrm{C}$. From the figures, we can see that the surface of J55 steel is attacked negligibly. In the presence of inhibitors, the surface condition is better at $30^{\circ} \mathrm{C}$ than at $105^{\circ} \mathrm{C}$. This shows the temperature effect of the inhibitor film stability on the metal surface.

\section{CONCLUSIONS}

The results of this research were promising and suggest that littered cigarette butts are point sources for prolonged heavy metal contamination. Furthermore, the apparent rapid release of multiple metals from littered cigarette butts increases the potential for acute harm to living biota. So recycling of cigarette butts will prevent the environmental pollutions and also reducing the corrosive problem occurring in the steel industryThe following conclusions can be drawn from the above investigations inhibitor extracted from discarded cigarette butts extract are very good inhibitor for J55 steel corrosion in $15 \% \mathrm{HCl}$ at $30^{\circ} \mathrm{C}$. They are not effective inhibitors for the similar system at $105^{\circ} \mathrm{C}$. The highest inhibition efficiencies of $99 \%$ and $61 \%$ are obtained for $30 \mathrm{C}$ and $105^{\circ} \mathrm{C}$ respectively at $6 \%$ concentration. It is mixed type of inhibitors, which obey Temkin's adsorption isotherm at both the temperatures.The SEM studies confirm the results obtained through weight loss, polarization and impedance techniques while seeing the morphology of the J55 steel surface.

\section{REFERENCES}

[1] Ach, A. (1993). Biodegradable plastics based on cellulose acetate. Journal of Advertiser. Retrieved from http://archive.advertiser.ie/pages/home.php American Cancer Society and Human Services, National Institutes of Health, National Cancer Institutes.

[2] Andrews, K. (2004, April 15) Get your butts off the street says Ó Neachtain. Galway Advertiser. Retrieved from http://archive.advertiser.ie/pages/home.php

[3] Borio,G.(2007).Tobacco Timeline. Tobacco BBS (212-982-4645).Retrieved from: http://www.tobacco.org

[4] City of Tacoma. (2010). Can it: Keep your butts out of the bay. Retrieved from consequenc smoking: 25 years of progress.A report of the Surgeon General, Contamination and Toxicology, 50, 205212.controversial issue. A tribute to Ernst L. Wynder. Chemical Research in Toxicology,

[5] Dane, A. J., Crystal, D. H., \& Kent, J. V. (2006). The detection of nitro pesticides in DC: Economic Research Service. Retrieved from http://usda.mannlib.cornell.edu/ Filtered-CigarettesBlamed-for-Huge-Rise-in-Type-of-Lung-Cancer.html

[6] Hoffmann, D., \& Hoffmann I. (1997). The changing cigarette, 1950-1995.Journal of Toxicology and Environmental Health, 50, 307-364.

[7] Hoffmann, D., \& Hoffmann I. (1998). Cigars: health effects and trends. In the Report of the National Cancer Institute. Smoking and Tobacco Control Monograph No. 9 (pp. 55- 104). NIH Pub. No. 984302 
[8] Hoffmann, D., \&Wynder, E. L. (1963). Filtration of phenols from cigarette smoke. Journal of the National Cancer Institute, 30, 67-84.Jiang,X., Zheng,Y.G., Ke,W., Corrosion inhibitor performances for carbon dioxide corrosion of $\mathrm{N} 80$ steel under static and flowing conditions, Corrosion, 61 (2005) 326-334.

[9] Juantao Zhang., Jun Zhao., Ningsheng Zhang., Chengtun Qu., Xiang Zhang., $\quad$ Synergized action of $\mathrm{CuCl}$ on recycling cigarette butts as corrosion inhibitor for $\mathrm{N} 80$ steel at $90^{\circ} \mathrm{c}$ in $15 \% \mathrm{HCl}$, Industrial \& Engineering Chemistry research,50 (2011) 72647272 .

[10] Litter Free Planet. (2009). Exposing the butts. Retrieved from Littoral Society, 25, 23-29.

[11] Longwood University.(2011). Cigarette Butt Litter, an educational project of Clean Virginia M. T. Nielsen (Eds.), Tobacco: production, chemistry and technology (pp. 353-387).Machine Measured Yields of Tar and Nicotine. Bethesda, MD: Department of Health

[12] Mackay, J., Eriksen, M., \&Shafey, O. (2006). The Tobacco Atlas, 2nd Ed. Atlanta, GA: The Macromolecular Science, Part A Pure and Applied Chemistry, 30(9), 733-740. Main stream and side stream cigarette smoke using electron monochromatic-mass Management, 29, 1192-1197

[13] Matthew, R.Simons. Report of Offshore technology conference (OTC) presentation, NACE International oil and gas production, May 2008

[14] I.N.Putilova, V.P.Barannik, and S.A.Balezin, Metallic Corrosion Inhibitors, Pergamon Press, Oxford, 1960, 30.

[15] J.D.Talati and J.M.Darji, J. Indian Chem. Soc., 1988, LXV, 94-99

[16] D.Agarwal, et al., Trans. SAEST, 2003, 38, 111-114.

[17] R.M.Issa, A.Z. El-Sonbati, A.A. El-indary, and H.M. Kera, Eur. Polym.J., 2002, 38, 561-568.
Behpour, M.; Ghoreishi, S. M.; Soltani, N.; SalavatiNiasari, M.The inhibitive effect of some bis-N, Sbidentate Schiff bases on corrosion behavior of 304 stainless steel in hydrochloric acid solution. Corros.Sci.2009, 51, 1073.

[19] Machnikova, E.; Whitmire, K. H.; Hackerman, N. Corrosioninhibition of carbon steel in hydrochloric acid by furan derivatives.Electrochim.Acta2008, 53, 6024.

[20] Li, P.; Lin, J. Y.; Tan, K. L.; Lee, J.Y.Electrochemical impedance and X-ray photoelectron spectroscopic studies of the inhibition of mild steelcorrosion in acids by cyclohexylamine. Electrochim.Acta1997, 42, 605.

[21] Cheng, Sh.; Cheng, Sh.; Liu, T.; Chang, X.; Yin,Y.Carboxymenthylchitosanas an ecofriendly inhibitor for mild steel in $1 \mathrm{M} \mathrm{HCl}$. Mater.Lett.2007, 61, 3276.

[22] Rafiquee, M. Z. A.;Saxena, N.; Khan, S.; Quraishi, M. A. Influenceof surfactants on the corrosion inhibition behaviour of 2-aminophenyl-5-mercapto-1oxa-3,4-diazole (AMOD) on mild steel. Mater.Chem. Phys.2008, 107, 528.

[23] Yurt, A.; Ulutas, S.; Dal, H. Electrochemical and theoreticalinvestigation on the corrosion of aluminium in acidic solution containing some Schiff bases.Appl. Surf. Sci. 2006, 253, 919.

[24] Zhang, Q. B.; Hua, Y. X. Corrosion inhibition of mild steel byalkylimidazolium ionic liquids in hydrochloric acid. Electrochim.Acta2009,54, 1881.

[25] Makhlouf, M. T.; Gomma, G. K.; Wahdan, M. H.; Khalil, Z. H.Effect of cyanine dye-solvent interaction on the electrochemical corrosion behavior of lowcarbon steel in acid medium. Mater. Chem. Phys. $\mathbf{1 9 9 5}, 40,119$

[26] United States Environmental Protection Agency. (2010) .Pesticides. Retrieved from www.epa.gov/pesticides/

Table 1: LC/MS Results of the Cigarette Butt Water Extracts

\begin{tabular}{|c|c|c|c|}
\hline Rt(mint) & Mol.Wt & Name & Peak Area Percent \\
\hline 1.06 & 177.2 & N-nitroso-nornicotine & $0.32 \%$ \\
\hline 1.15 & 162.2 & Nicotine & $1.43 \%$ \\
\hline 1.29 & 176.2 & Cotinine & $0.11 \%$ \\
\hline 1.71 & 164.2 & 2,2dimethyl-2,3-dihydrobenzofuran-7-ol & $0.07 \%$ \\
\hline 2.13 & 270.1 & 5-(4,6-dichloropyridin-3 yl)pyridine-1(2H)-carboxiamide & $0.02 \%$ \\
\hline 3.23 & 271.1 & 6-(2,6-dicholorophenoxy)pyrimidine-2,4-diamine & $0.04 \%$ \\
\hline 4.043 & 610.5 & Rutin & $0.01 \%$ \\
\hline
\end{tabular}


Table 2: Chemical composition of J55 tubular steel

\begin{tabular}{|c|c|c|c|c|c|c|}
\hline Material & $\mathrm{c}$ & $\mathrm{Mn}$ & $\mathrm{si}$ & $\mathrm{p}$ & $\mathrm{s}$ & $\mathrm{Fe}$ \\
\hline J55steel & 0.33 & 1.45 & 0.25 & 0.04 & 0.06 & 97.8 \\
\hline
\end{tabular}

Table3: Mass loss parameters of $\mathrm{J} 55$ steel in $15 \%$ commercial $\mathrm{HCl}$ with and without various concentrations of Inhibitors at $30^{\circ} \mathrm{C}$ and $105^{\circ} \mathrm{C}$

\begin{tabular}{|c|c|c|c|c|c|c|c|}
\hline \multirow{2}{*}{ S.No } & \multirow{2}{*}{ I.C (\%) } & \multicolumn{2}{|c|}{ Weight loss(mg) } & \multicolumn{2}{c|}{$\begin{array}{c}\text { Corrosion } \\
\text { rate(mmpy) }\end{array}$} & \multicolumn{2}{c|}{ Inhibitor efficiency } \\
\cline { 3 - 8 } & & $30^{\circ} \mathrm{C}$ & $105^{\circ} \mathrm{C}$ & $30^{\circ} \mathrm{C}$ & $105^{\circ} \mathrm{C}$ & $30^{\circ} \mathrm{C}$ & $105^{\circ} \mathrm{C}$ \\
\hline 1 & BLANK & 1434 & 3672 & 165 & 427 & - & - \\
\hline 2 & $2 \%$ & 195 & 1762 & 22 & 204 & 86 & 52 \\
\hline 3 & $4 \%$ & 127 & - & 15 & - & 91 & - \\
\hline 4 & $6 \%$ & 13 & 1432 & 1.5 & 166 & 99 & 61 \\
\hline 5 & $8 \%$ & 10 & - & 1.2 & - & 99 & - \\
\hline 6 & $10 \%$ & 8 & 1173 & 1 & 136 & 99 & 68 \\
\hline
\end{tabular}

Table4: Polarization parameters of $\mathrm{J} 55$ steel in $15 \%$ commercial $\mathrm{HCl}$ with and without various concentrations of Inhibitors at $30^{\circ} \mathrm{C}$ and $105^{\circ} \mathrm{C}$

\begin{tabular}{|c|c|c|c|c|c|c|c|c|c|c|c|}
\hline \multirow[t]{2}{*}{ S.No } & \multirow[t]{2}{*}{$\begin{array}{l}\text { I.C } \\
(\%)\end{array}$} & \multicolumn{2}{|c|}{$\begin{array}{c}\mathrm{E}_{\mathrm{corr}} \\
(\mathrm{mV} \text { vs.SCE) }\end{array}$} & \multicolumn{2}{|c|}{$\begin{array}{c}\mathrm{b}_{\mathrm{a}} \\
\text { (mV/decade) }\end{array}$} & \multicolumn{2}{|c|}{$\begin{array}{c}\mathrm{b}_{\mathrm{c}} \\
(\mathrm{mV} / \text { decade })\end{array}$} & \multicolumn{2}{|c|}{$\begin{array}{c}\mathrm{I}_{\text {corr }} \\
\left(\mu \mathrm{A} / \mathrm{cm}^{2}\right)\end{array}$} & \multicolumn{2}{|c|}{$\begin{array}{c}\text { Inhibitor } \\
\text { efficiencies } \\
(\%)\end{array}$} \\
\hline & & $30^{\circ} \mathrm{C}$ & $105^{\circ} \mathrm{C}$ & $30^{\circ} \mathrm{C}$ & $105^{\circ} \mathrm{C}$ & $30^{\circ} \mathrm{C}$ & $105^{\circ} \mathrm{C}$ & $30^{\circ} \mathrm{C}$ & $105^{\circ} \mathrm{C}$ & $30^{\circ} \mathrm{C}$ & $105^{\circ} \mathrm{C}$ \\
\hline 1 & Blank & -466 & -456 & 97 & 205 & 111 & 221 & 771 & 135000 & - & - \\
\hline 2 & $2 \%$ & -444 & -483 & 87 & 110 & 165 & 248 & 382 & 60900 & 50 & 55 \\
\hline 3 & $4 \%$ & -456 & - & 122 & - & 160 & - & 250 & - & 68 & - \\
\hline 4 & $6 \%$ & -461 & -437 & 115 & 146 & 148 & 257 & 200 & 56300 & 74 & 58 \\
\hline 5 & $8 \%$ & -459 & - & 111 & - & 172 & - & 164 & - & 79 & - \\
\hline 6 & $10 \%$ & -467 & -468 & 101 & 176 & 154 & 178 & 130 & 47600 & 83 & 65 \\
\hline
\end{tabular}

Table5: Impedance parameters of $\mathrm{J} 55$ steel in $15 \%$ commercial $\mathrm{HCl}$ with and without various concentrations of Inhibitors at $30^{\circ} \mathrm{C}$

\begin{tabular}{|c|c|c|c|c|}
\hline S.No & $\mathrm{I} . \mathrm{C}(\%)$ & $\mathrm{R}_{\mathrm{ct}}\left(\Omega \mathrm{cm}^{2}\right)$ & $\mathrm{C}_{\mathrm{dl}}\left(\mu \mathrm{Fcm}{ }^{-2}\right)$ & $\mathrm{I} . \mathrm{E}(\%)$ \\
\hline 1 & Blank & 32 & 265 & - \\
\hline 2 & $2 \%$ & 76 & 111 & 58 \\
\hline 3 & $4 \%$ & 79 & 109 & 59 \\
\hline 4 & $6 \%$ & 115 & 74 & 72 \\
\hline 5 & $8 \%$ & 173 & 49 & 81 \\
\hline 6 & $10 \%$ & 274 & 31 & 88 \\
\hline
\end{tabular}


Table 6: Effect of temperatures on various thermodynamic parameters

\begin{tabular}{|c|c|c|c|c|c|c|c|c|c|}
\hline \multirow{2}{*}{ S.No. } & \multirow{2}{*}{$\begin{array}{c}\text { Inhibitor } \\
\text { name }\end{array}$} & \multirow{2}{*}{$\begin{array}{c}E_{a} \\
\left(\mathrm{~kJ} \mathrm{~mol}^{-1}\right)\end{array}$} & \multirow{2}{*}{$\begin{array}{c}\mathrm{Q}_{\mathrm{ads}} \\
\left(\mathrm{kJ} \mathrm{mol}^{-1}\right)\end{array}$} & \multicolumn{2}{|c|}{$\begin{array}{c}\Delta \mathrm{G}_{\mathrm{a}}^{\mathrm{o}} \\
\left(\mathrm{kJ} \mathrm{mol}^{-1}\right)\end{array}$} & \multicolumn{2}{|c|}{$\begin{array}{c}\Delta \mathrm{H}_{\mathrm{a}}^{\mathrm{o}} \\
\left(\mathrm{kJ} \mathrm{mol}^{-1}\right)\end{array}$} & \multicolumn{2}{|c|}{$\begin{array}{c}\Delta \mathrm{S}_{\mathrm{a}}{ }^{\mathrm{O}} \\
\left(\mathrm{kJ} \mathrm{mol}^{-1}\right)\end{array}$} \\
\hline & & & & $30^{\circ} \mathrm{C}$ & $105^{\circ} \mathrm{C}$ & $30^{\circ} \mathrm{C}$ & $105^{\circ} \mathrm{C}$ & $30^{\circ} \mathrm{C}$ & $105^{\circ} \mathrm{C}$ \\
\hline 1 & Blank & 11380 & - & - & - & 8863 & 8195 & - & - \\
\hline 2 & Inhibitor & 60677 & $\begin{array}{l}-46334 \\
\end{array}$ & -37331 & -34951 & 58160 & 57494 & 58283 & 57584 \\
\hline
\end{tabular}

\section{Captions for Figures}

Figure - 1: Variation of inhibitor efficiencies as a function of InhibitorConcentrations at $30^{\circ} \mathrm{C}$ and $105^{\circ} \mathrm{C}$

Figure - 2a: Polarization curves of J55 steel in $15 \%$ commercial $\mathrm{HCl}$ Without various concentrations of Inhibitors at $30^{\circ} \mathrm{C}$ and $105^{\circ} \mathrm{C}$.

Figure - 2b: Polarization curves of J55 steel in $15 \%$ commercial $\mathrm{HCl}$ with Various concentrations of Inhibitors at $30^{\circ} \mathrm{C}$ and $105^{\circ} \mathrm{C}$.
Figure - 3:Impedance curves of J55 steel in 15\% commercial $\mathrm{HCl}$ with and Without various concentrations of Inhibitors at $30^{\circ} \mathrm{C}$.

Figure -4 : Tem kin's adsorption isotherm plot for inhibitors at $30^{\circ} \mathrm{C}$ and $105^{\circ} \mathrm{C}$.

Figure - 5:SEM photographs of J55 steel in 15\% commercial $\mathrm{HCl}$ with and without $10 \%$ inhibitors at $30^{\circ} \mathrm{C}$ and $105^{\circ} \mathrm{C}$.
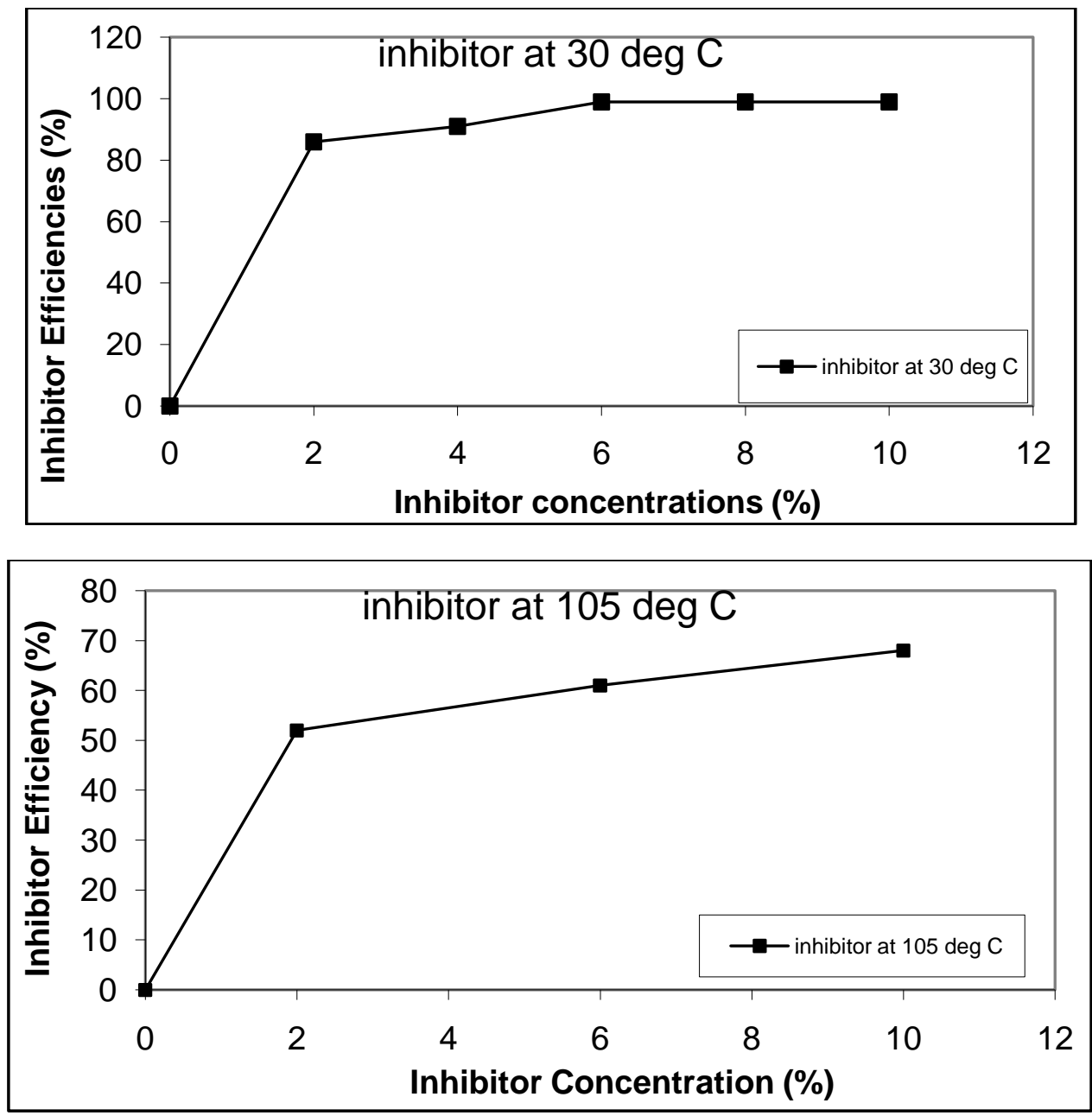

Fig. 1: Variation of inhibitor efficiencies as function of inhibitor concentrations at $30^{\circ} \mathrm{C}$ and $105^{\circ} \mathrm{C}$ 

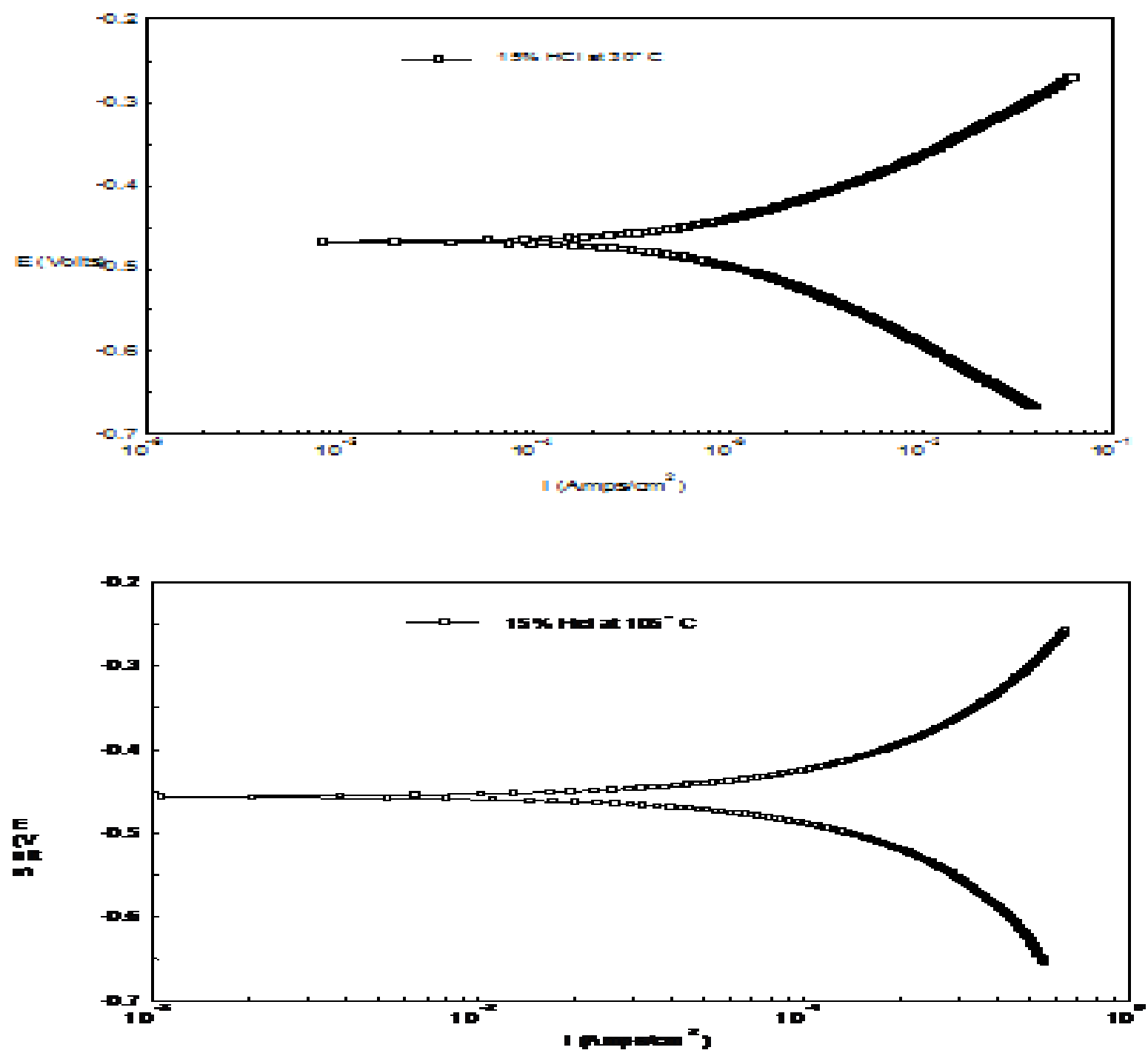

Fig.2a: Polarization curves of $\mathrm{j} 55$ steel in $15 \%$ commercial $\mathrm{HCl}$ without inhibitors at $30^{\circ} \mathrm{C}$ and $105^{\circ} \mathrm{C}$

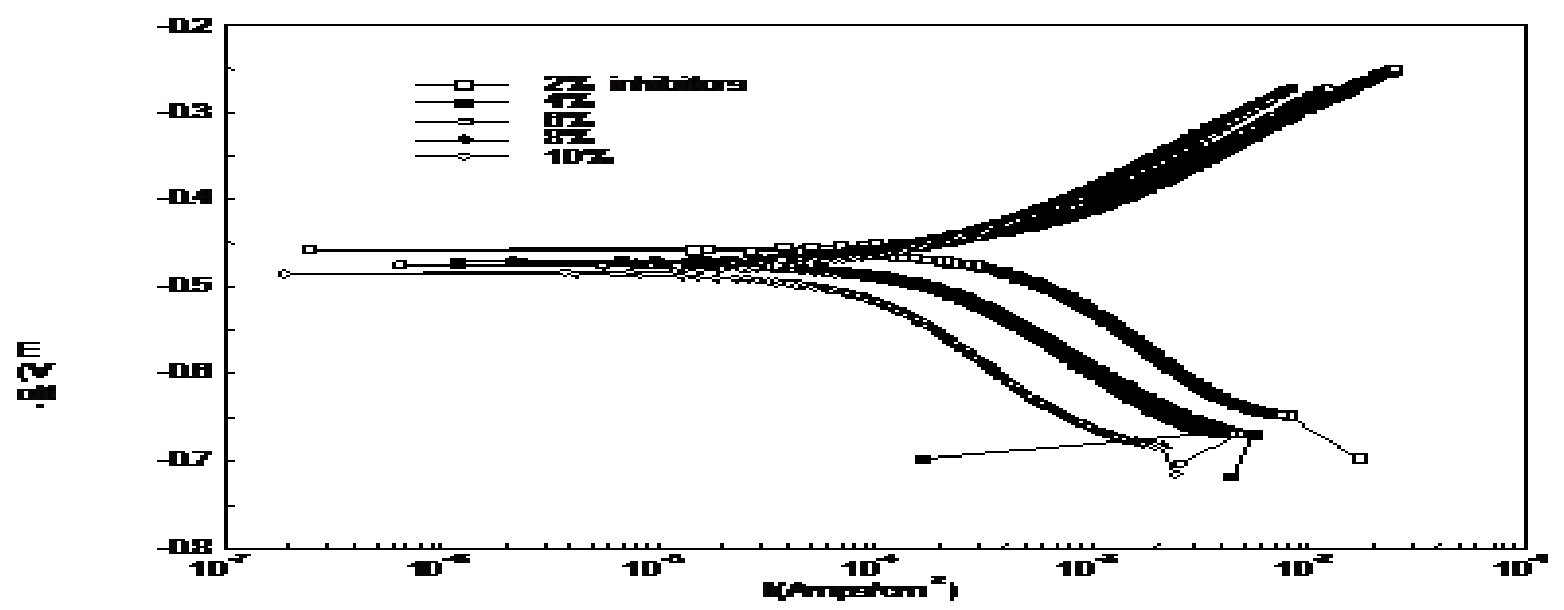




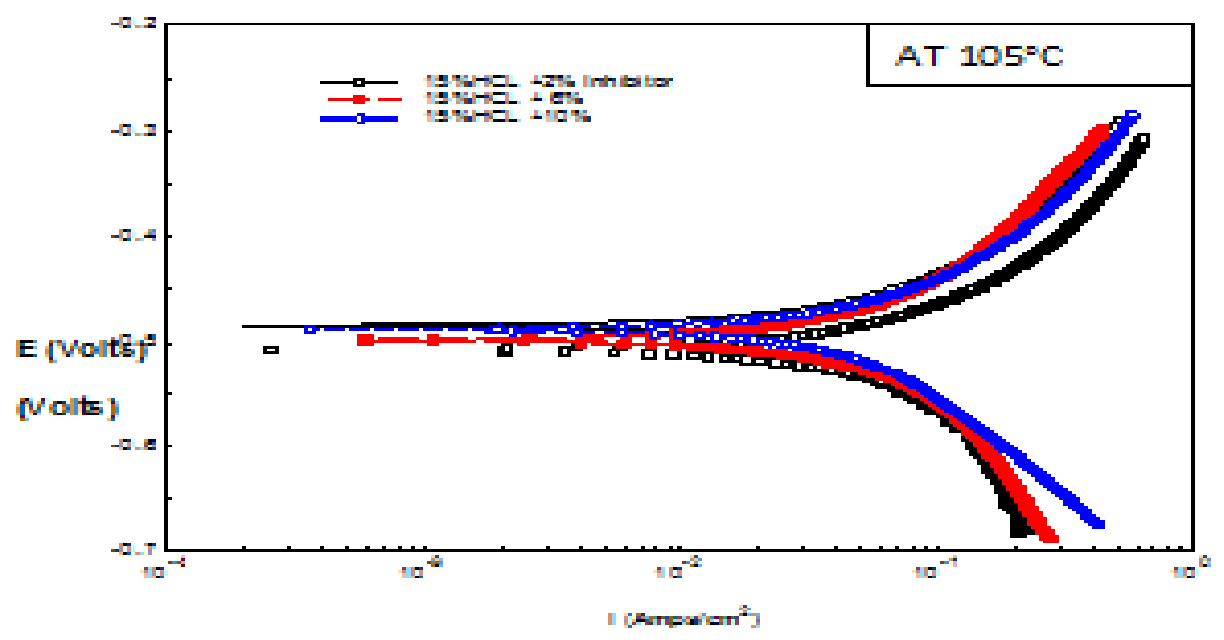

Fig. 2b: Polarization curves of $\mathrm{J} 55$ steel in $15 \%$ commercial $\mathrm{HCl}$ with various concentrations of inhibitors at $30^{\circ} \mathrm{C}$ and $105^{\circ} \mathrm{C}$.
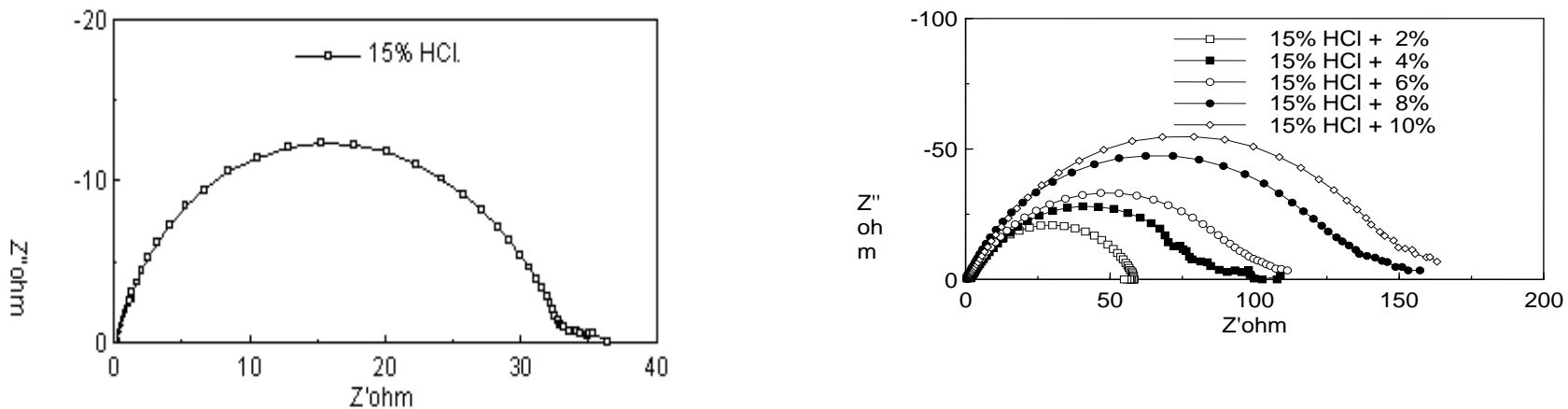

Fig.3: Impedance Curves of $\mathrm{J} 55$ steel in $15 \%$ commercial $\mathrm{HCl}$ with and without various concentrations of Inhibitors at $30^{\circ} \mathrm{C}$.

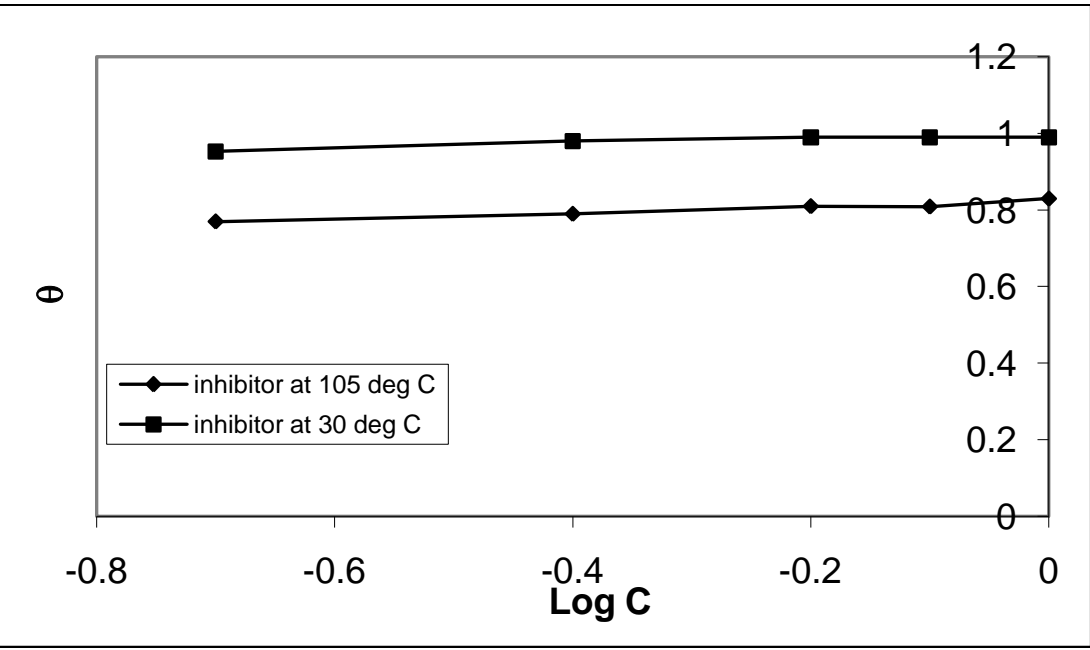

Fig. 4 - Tem kin's adsorption isotherm plot for inhibitor on J55 Oil well tubular steel 


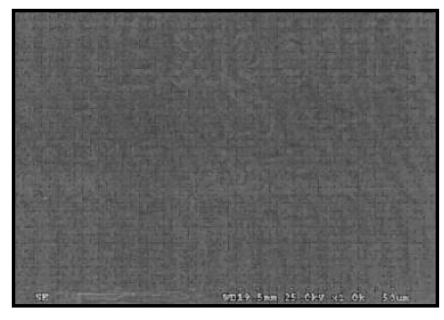

(a) Polished J55 steel (PJS)

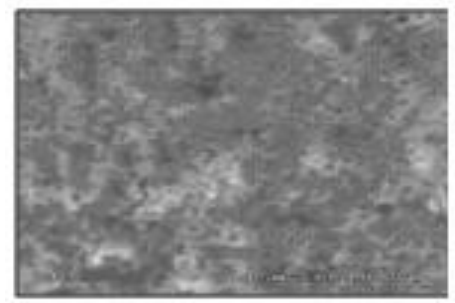

(b) $\mathrm{PJS}$ in $15 \% \mathrm{HCl}$ at $30^{\circ} \mathrm{C}$

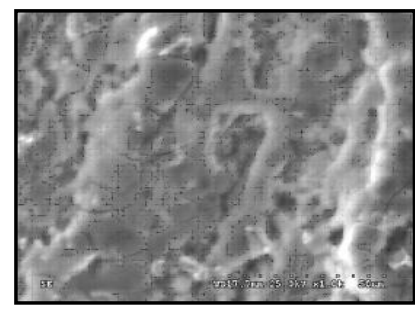

(d) PJS in $15 \% \mathrm{HCl}$ with $6 \%$ Inhibitor at $30^{\circ} \mathrm{C}$

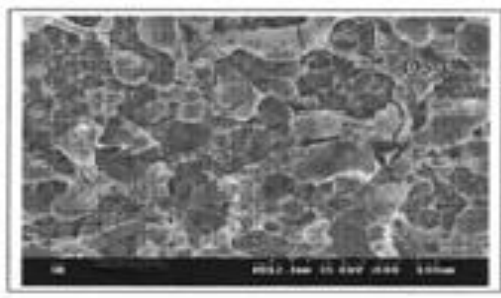

(c) PJS in $15 \% \mathrm{HCl}$ at $105^{\circ} \mathrm{C}$

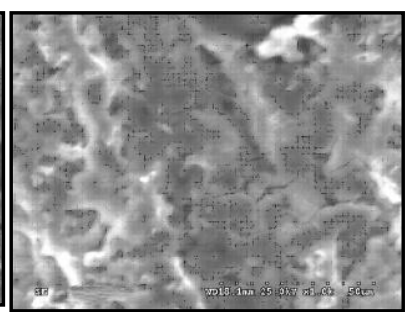

e) PJS in $15 \% \mathrm{HCl}$ with $6 \%$ Inhibitor at $105^{\circ} \mathrm{c}$

Fig. 5(a to e): SEM Photographs of J55 Steel in $15 \%$ commercial $\mathrm{HCl}$ with and without $6 \%$ Inhibitors at $30^{\circ} \mathrm{C}$ and $105^{\circ} \mathrm{C}$ 